\title{
Imam Ali Shrine, institution and cultural monument: the implications of cultural significance and its impact on local conservation management
}

\author{
S. K. Abid \\ School of Architecture, University of Sheffield, UK
}

\begin{abstract}
The Imam Ali Shrine is located in the heart of Najaf old town, the historic Islamic pilgrimage city. It is one of the great icons of Islamic religion and architecture, especially for the Shi'a, and is regarded by many as the finest masterpiece of Iraqi heritage. This paper, therefore, focuses specifically on the Shrine, whose construction led directly to the establishment of the surrounding historic city. The main aims are to understand what has happened over time, and who the key players now are in terms of conservation management on the ground. Consequently, it is important to explain the historical stages of the emergence of the shrine, and the events which take place within it. Critically, local decision makers have prioritised how to accommodate and receive visitors to the holy Shrine, without paying attention to protecting its cultural heritage and local identity: gradually, this has led to the demolition of many important historical buildings and features surrounding the Shrine. However, the Shrine remains a key Najaf landmark and is religiously significant for Islamic cities in general.

This paper is organised around two main sections, the first section addresses the historical and cultural context of the Shrine in terms of its historical development and significance. The second section focuses on the external (national) and internal (local) forces that have acted on the Shrine as a building. It details specific projects in depth to discover their remit and impact on the Shrine's historic fabric.
\end{abstract}

Keywords: Najaf, Imam Ali Shrine, cultural heritage, conservation management. 


\section{Introduction}

Undoubtedly, the Imam Ali Shrine has a special character and a significant cultural heritage. However, Najaf as a pilgrimage city has many problems which the central and local government have been trying to resolve through development projects. The main concern is that these projects have led to the demolition of the cultural heritage of Najaf, and the removal of the local identity of the city. Moreover most development solutions have been adopted from elsewhere rather than being specific to Najaf and, ultimately, the city will be left without history or historic character. Consequently, Najaf's buildings in general, and the Shrine in particular, are under threat in terms of safeguarding cultural heritage. This paper is, therefore, a case study of conservation management in Iraq in general with particular reference to Najaf. It demonstrates how the local and national authorities perceived the Shrine as a historical building during the period before and after 2003 in terms of its protection, management, and development work. It attempts to shed light on the Shrine from its establishment to the present day, in order to answer the question of how effectively its heritage has been designated, protected, and managed. In this particular, the best starting point is to shed light on the historical evolution of the Shrine. To reiterate, this case study is used to justify and understand the application of conservation management framework before and after 2003 in order to support Najaf to become a contemporary city through protecting and enhancing its cultural heritage.

\section{The Shrine's evolution}

To understand the importance and significance of cultural heritage sites in terms of protection policies and management, heritage practitioners normally appraise the historical development of any site, documenting the history of changes in its form and fabric [1]. In this particular, the research is going to explain and present the Shrine as a building from its established to present. First of all, In 599 Imam Ali was born in the Sacred House the focus of daily prayers within the Islamic tradition (Ka'ba) in Mecca. In his relationship to the prophet Mohammed, whose daughter he married, and as a successor as Caliph in his own right, Imam Ali is an important figure in Islamic history and he continues to be venerated by Muslims. Historically, Najaf was to become one of the most important cities in the Islamic World, when Imam Ali chose Kufa (now a suburb of Najaf) as the Islamic capital in 656. More than a half century after his death in 661, the Imam Ali tomb was founded, and as a result a new district developed around it. In the following two centuries, the Shrine location grew in size and status as a distinct urban district, managed by the adjacent city of Kufa for most of its administrative affairs [2].

The Shrine has a long history starting from 786 when the first building was constructed as a small room and dome made from clay, with four portals. Later, in the last two decades of the 9th century, perimeter walls were added around the tomb of Imam Ali containing rooms used for studying and for rest [3]. Since 900 A.D the Shrine has been periodically rebuilt, and the largest building was 
constructed in 979. This building remained for over five centuries before being completely destroyed in a fire [4, p. 39]. The current design dates from the Safavid era, when Al-Shaekh Al-Bahaee proposed a new design in 1621. It was built in 1630, with the dome reconstructed and the Shrine extended. Local materials from the area surrounding Najaf were used with work taking three years [4, p. 21] (Figures 1 and 2). Since the middle of the $16^{\text {th }}$ century to the present, the Shrine has sat as a focal point in the old town. Many projects have been done both around and on it, but it still stands as a corner stone in the heart of the city.

The Shrine architectural significance comes from its visual qualities, in addition to the external and internal design elements of the Shrine. Although the Shrine has functioned as a pilgrimage site for twelve centuries, architecturally it dates from the $17^{\text {th }}$ century, and the contemporary Shrine complex is made up of a number of historically distinct elements of which just one third are original [5]. The current main architectural elements of the Shrine are: the outer wall, the 5 main portals, the courtyard (Sahan), the golden Iwan, the two golden Minarets, the Shine clock, the golden dome, and the tomb of Imam Ali (Figure 3). All together, they shape a unique design that has enough value to become a focal point for the identity of the city.

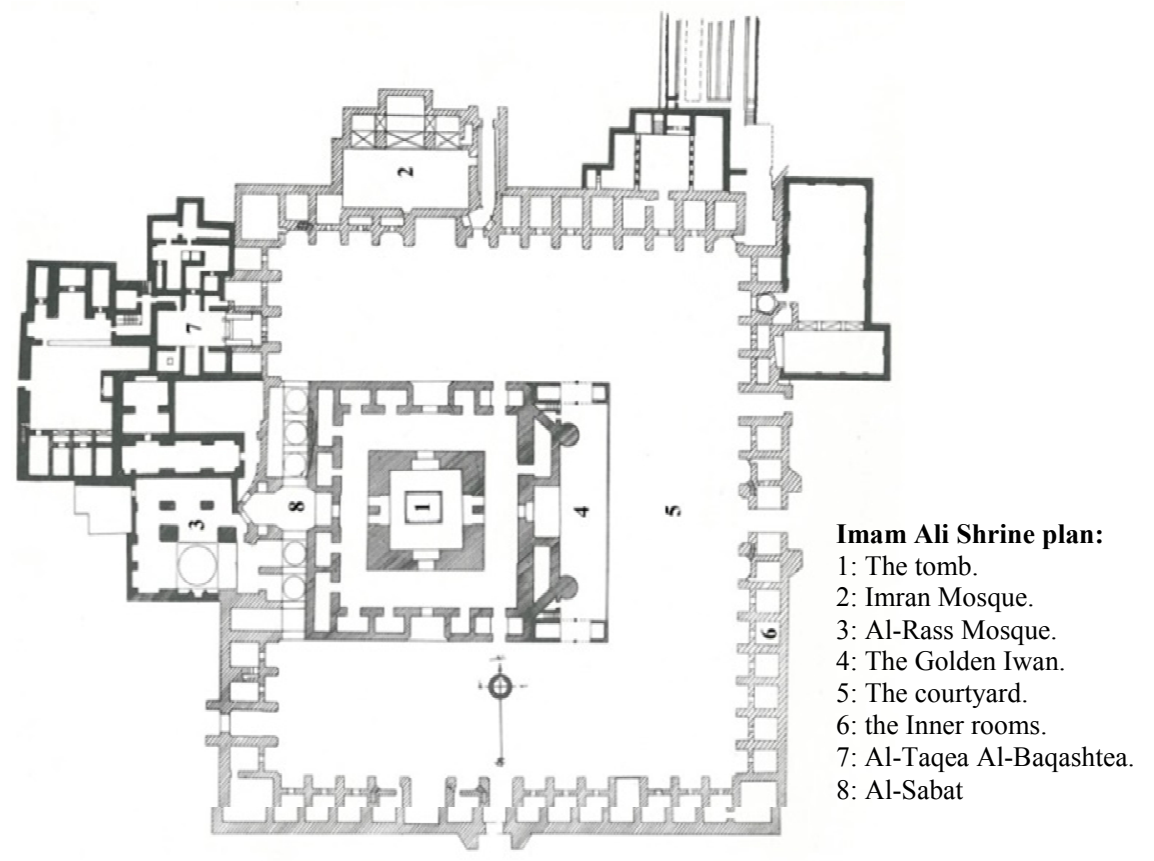

Figure 1: $\quad$ The Imam Ali Shrine plan in 1969 [6]. 

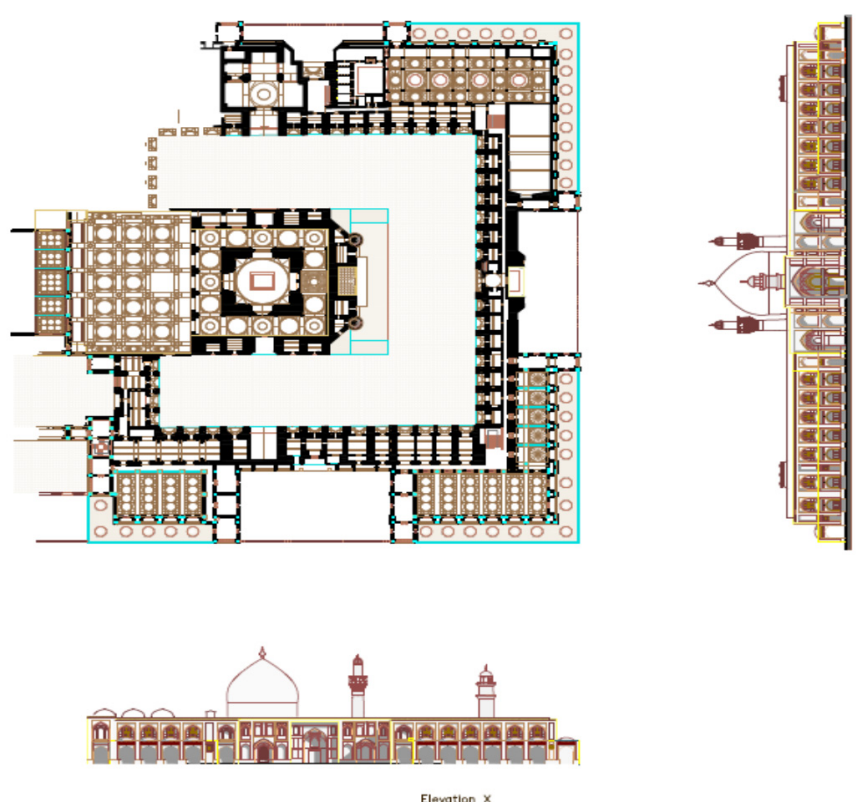

Figure 2: The current Imam Ali Shrine plan and sections [7].
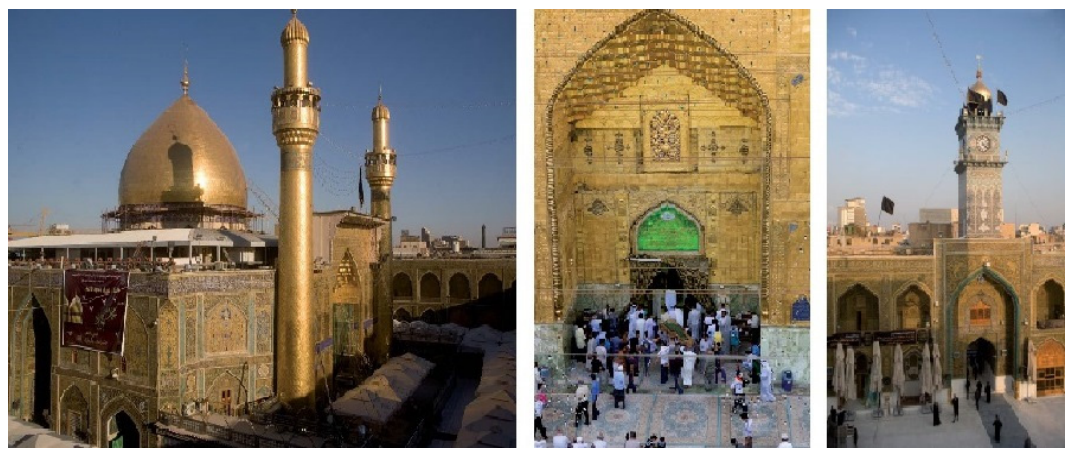

Figure 3: The main architectural elements of Imam Ali Shrine [8].

The Shrine complex is located in a large paved pedestrian square, covering a great area. There are commercial frontages on the perimeter and some secondary religious sites beyond the security fence [9]. Despite the approach demolitions that lead loosened the relationship between the shrine and its surroundings, the shrine is still standing as a jewel in the core of the city. Therefore, it can be said that there is a strong relationship between the Shrine and Najaf old town. Overall, although not included in the World Heritage list, the architectural significance of the Shrine occupies a prominent position in Iraqi memory and Shia culture. 


\section{The external and internal forces that have acted on the cultural heritage of the Shrine}

\subsection{The external forces (central government)}

In modern Iraqi history, until 2003 the Iraqi central government was the key to all decisions in terms of managing and protecting cultural heritage at any site. Generally, central government interventions had a catastrophic impact in terms of heritage protection on the ground. In this particular, Kamona (an Iraqi architect born in Najaf) has argued that the Shrine was neglected in all development projects, going so far as to say that the urban players and the government have contributed to the destruction of Najaf's urban form: "the Shrine suffered from neglect continuously, and development process was hasty" [10]. In fact, many factors have had considerable impact in terms of development of the Shrine on the ground. These include direct and indirect factors, which have either negative or positive impact on the historic character. Inappropriate Shrine development projects could be catastrophic in terms of heritage protection. The key interventions took place in 1949, 1986, and then during the 1990s. As such, this part reviews the main projects in which the central government was the key decision maker to understand how heritage has been protected on the ground.

Before 1949, Najaf old town had an organic fabric and coherent form in the shape of a ring with the Shrine in the centre, surrounded by four neighbourhoods. In this sense, anyone who walks around the urban fabric along narrow zigzagging paths cannot see a direct path to the Shrine. Only when they are close to the Shrine do they enter into the wide and dominant space. This sudden move makes visitors feel reverence and faith, appropriate to holy places [11]. Accordingly, to go through this path leads to the achievement of attraction between visitors and the shrine, seen as the golden domes and minarets, as they appear and disappear as a result of the constantly changing turns in the paths. The urban spaces surrounding the Shrine can be characterized as an organization, gradient, streamlined and aesthetic [12]. Overall, the town shape may be likened to a solid block, closely interconnected with the adjacent urban fabric. This reflects the fact that the Shrine evolved over time and in a coherent complement each other and as a single unit. However, during the 20th century many significant events took places which have had significant impact on the city morphology. In 1949 the historical area around the Shrine was demolished to facilitate the movement of vehicles and visitors, so this event weakened the urban fabric (Figures 4 and 5).

From the perspective of heritage protection, the other significant change, aesthetically and stylistically, was to the external walls of the Shrine. The outer wall was clear and solid, and local materials were used to build it. In this particular case, after removing the buildings around the Shrine in the 1949, the exterior walls had become isolated from the surrounding buildings. Consequently a new skin wall was built, using some Islamic engravings and arches to decorate it [13]. It should be noted that Najaf's local community considered its shape to be unique and beautiful. Its materials (bricks clay) mark a return to the Sumerian civilization, and its decoration evokes Islamic civilization. However, Kamona's main concern 
that considered the interfaces of outer walls as sculptures building, indeed this quotation for the Western concepts. Thus, the Shrine has been isolated from the urban fabric surroundings, and new urban problems began to appear [14].

Later, in 1986 the decision to remove Al-Imarah (the historical neighbourhood) in order to create a new open space close to the Shrine, weakening the Shrine as a central space in the old town, as well as isolating it from the urban surroundings. In this particular, the central government which was represented by the urban planning authority, tried to change the built environment of the old town [15]. The government undertook this intervention to improve and develop the old town in order to be able to accommodate visitors, and make the city as a contemporary city (Figure 6).

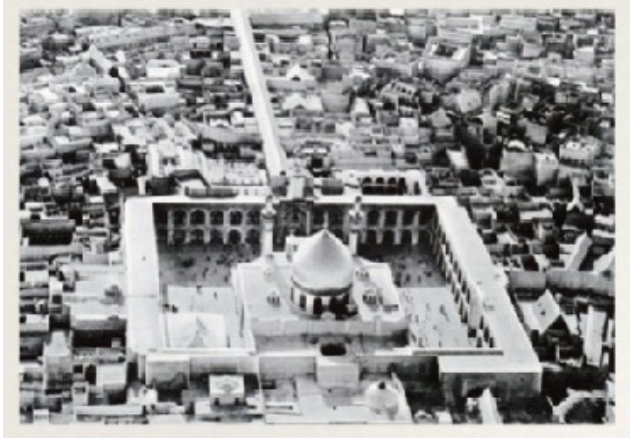

The Shrine before inciaion streets

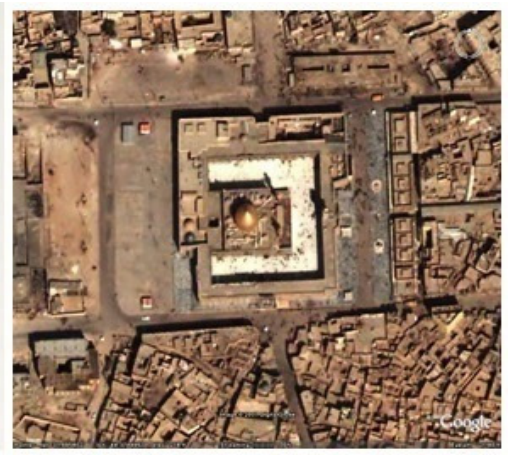

The Shrine after 2003

Figure 4: The Shrine before and after opened the streets.

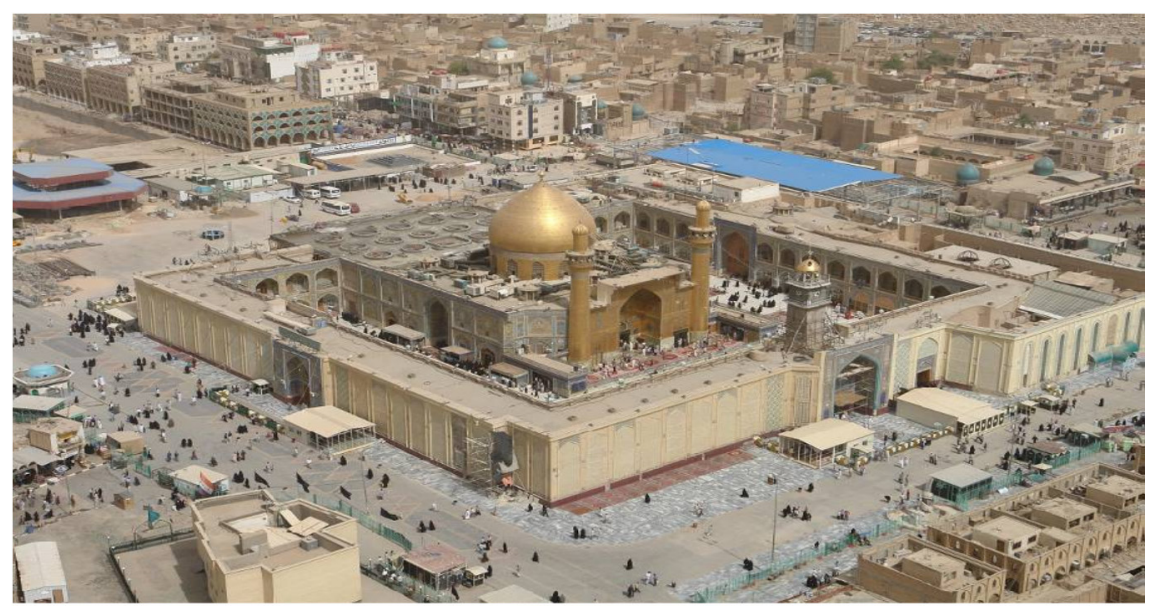

Figure 5: Arial view shows removing buildings surrounding the Shrine [16]. 


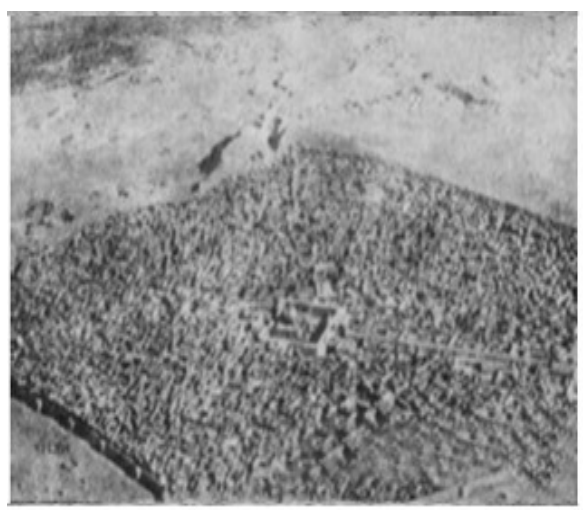

1930 s

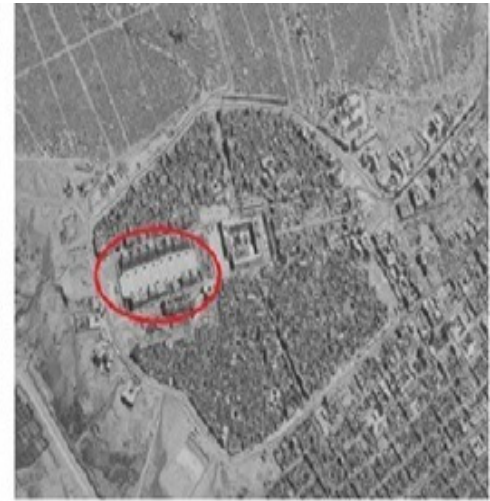

1990 s

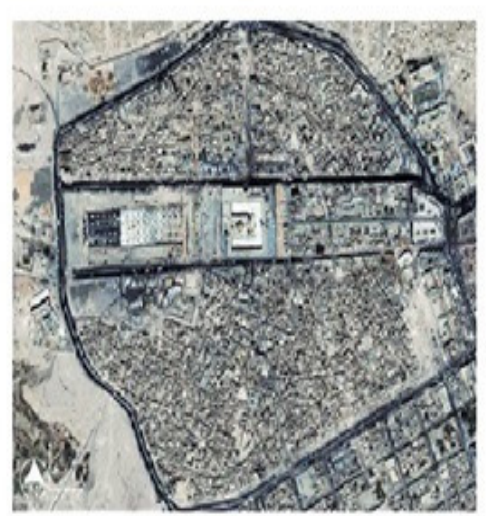

2012

Figure 6: Najaf old town in different periods (1930s, 1990s, and 2012).

Then, in 1998 the central government proposed to create a city of visitors next to the Shrine over the area that was removed in 1986, covering a total area of around $80,000 \mathrm{~m}^{2}$. The designer proposed renovation work that included the demolition of the old irregular type buildings, and their replacement with modern regular types. However, this led to the destruction of many of the historic and heritage sites during the renovation process [17]. There was deep disagreement about this project. On the one hand the government's intention was to improve and develop the Shrine and its surrounding area and the Ba'ath government honoured researchers who dealt with heritage protection several times. On the other hand, they removed one of the most significant areas that had many historical features and values, and left it for more than decade as a flat area. In fact there were some political and religious reasons that led to the removal of this area. Nevertheless, most of the researchers and local community that I interviewed believe that there were some political and religious issues which led to the demolition of the area (Figure 7). As we have already seen, the project didn't finish until 2008 when the Shrine institution has decided to extend the Shrine over this area. 


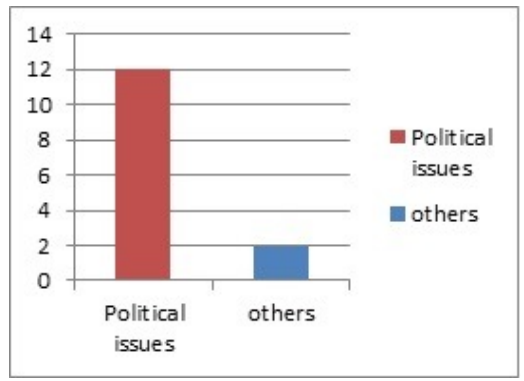

Figure 7: The reasons for demolishing the Al-Imarah neighbourhood historic area.

In a broader picture, the first reason of these interventions suggested by interviewees was to reduce the activity of religious scholars because this area had many traditional religious schools, and there was also an attempt to decrease the numbers of visitors to the Shrine. As a result Najaf lost many significant buildings, including traditional religious schools and historic houses dating back over 200 years. It marked the culmination of the policies of the former regime, and made it very difficult to return to the city's original layout. These policies were rooted among decision makers; therefore it will need time and considerable effort to get rid of them. To reiterate, the government's perspective is continuing the same negative aspects in terms of heritage protection, although the place and source of decision-making has changed. By doing so, Imam Ali Shrine has continued to suffer from mismanagement and has lost many of its historical elements.

It should be noted that all of these interventions affected the area surrounding the Shrine, but not the Shrine building itself. Therefore, the interventions were confined inside the Shrine on simple maintenance that perpetuates age of it. It was stated before that the central government was the key player in managing the Shrine and most other institutions until 2003. Accordingly, it was an institution related to the central government through the Ministry of Religious Affairs, and most of the regulations and decisions in terms of the Shrine came from the Ministry. At that time, the central approach aimed to weaken the authority of the religious scholars through a policy of secularisation. In fact, far too little attention was paid to manage and protect the cultural heritage of the Shrine and other historical buildings at that time. Moreover, little money was spent on protecting, developing and managing the Shrine, so it is hard now to see and understand what was done.

In fact, the Shrine was forced to transfer most of the money that was paid inside the grave by the visitors to the central regime without using it to improve the Shrine or the old town. Moreover, because of the cruelty of the dictatorial regime, nobody could complain or ask about this situation. Up to now, there has been little agreement on how to manage the Shrine as an institution, in terms of protecting its cultural heritage and its religious significance. As a result, the Shrine has suffered from neglect, and it gradually was turning to receiving visitors; after it was the main source of knowledge and cultural heritage. After 2003 the central 
government influence receded in decision making in terms of the Shrine and the old town, however, its cultural heritage still under threat.

\subsection{The internal forces (local decisions makers)}

The current millennium has seen rapid growth in many aspects of developing and managing the Shrine; with the new political regime, many forces have appeared as new key powers in decision-making. Since 2003 the religious scholars, Najaf local government and the General Secretariat of the Imam Ali Shrine institution are the key players in terms of developing, managing, and saving the Shrine and its surrounding area.

First of all, in 2005 the first project inside the Shrine building was carried out. The main reason was to expand and develop the space around the Imam Ali's tomb, and to cope with increasing numbers of visitors. To achieve this, the Al-Rass mosque was chosen, because it was the biggest mosque inside the Shrine building, and suffered from neglect (Figure 8). Historically, it was a very wide space which had many cylindrical spaces lying to the west of the main building of the holy Shrine. It is called the Mosque of the Al-Rass, (i.e. the Head) because it lies in the direction of the head of the holy tomb of the Imam Ali. Judging from materials used for the walls, its architectural shape and style, Mahboba believes that it was built at the same time as the Shrine [18]. Many events took place in it; indeed, one of the significant events in this mosque was the signing of the Najaf peace treaty between Shia and Sunni in 1743. In fact the religious scholars were the key players in this agreement, and it opened a new page in the Islamic history between Shia and Sunna [19]. As such, the mosque has great values which come from its position beside the tomb (religious) and its long history, in addition to its architectural style.
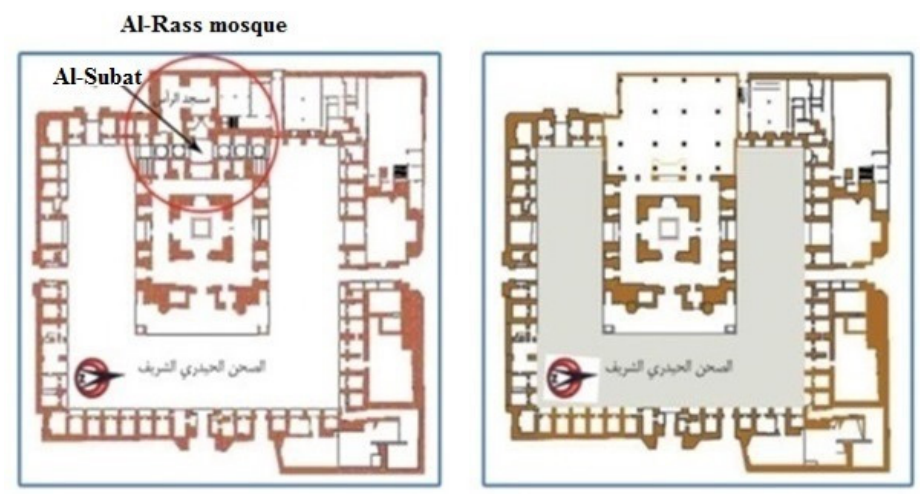

Figure 8: Detailed plan of the Al-Rass mosque before and after the project.

As stated previously, the Shrine institution tried to accommodate the huge number of visitors safely. Accordingly, the 2005 project demolished the Al-Rass mosque and removed many important details and features in order to create a new big space inside the Shrine, close to the tomb (Figure 8) [20]. There was a strong 
conflict among key players and caretakers in terms of protecting the place. Consequently, Attia (Lecturer at University of Kufa) stated that Al-Rass mosque had lot of closed spaces as small cemeteries and storage rooms, therefore, visitors could not reach the mosque. In addition, the Ba'ath regime had changed it step by step, therefore, during the construction of the project it was found that some parts had been built by using concrete and modern decorations, and it was in very bad condition. Hence, it was evidence that it was not part of the original Shrine. In addition, it was higher than the Shrine level; therefore, it was very difficult to open it toward the Shrine to be as one space. Therefore, the Shrine General Secretary had chosen to extend the Shrine [21]. All of these points support the Shrine Secretary's decision to choose Al-Rass mosque place to extend the Shrine and receive more visitors safely. So far, the project opened a new era in terms of developing the Shrine.

Perhaps one of the most serious defects of the present management of the Shrine is the fact that the decision-makers see heritage protection as a secondary concern. In this particular, Kamona highlighted the tension between those who advocate for heritage protection, and what has been done on the ground. A small committee group was formed to evaluate the project before its implementation, under the guidance of the religious scholars. The group was detached from the Shrine institution, and it consisted of some architects and specialists in architecture field. They felt that it should stop working with this project, because it recognized its cultural, historical and architectural significance [22]. But they offered no solutions; therefore, the Shrine administration decided to speed up the work and demolished the Al-Subat and the Al-Rass mosque. This marks the culmination of what is happening on the ground in terms of lack of genuine interest in cultural heritage. In fact, there is potentially a conflict between those who are calling for protection of cultural heritage and those who believe that accommodating the visitors should be the priority. The dominant approach to demolish the Shrine's cultural heritage has been pursued in all development projects, whether directed from central or local government.

However, the new project can be criticised on aesthetic, stylistic and historical grounds. It damaged the physical composition and failed to consider values that come from the place. The old plan clearly shows the order of unity, and the relations among the Shrine spaces, in addition to the proportion between the open and closed space; and the spaces' shapes. This project damaged the physical composition by destroying the systematic order of the space. As a result, the new space appears strange, and lacks a sense of order because of using a new architectural and construction style. Indeed, the main weakness of this project was the failure to address the issues of how to balance among heritage protection, conservation approach and visitors' needs.

\section{Conclusions}

The Imam Ali Shrine is the most important contributor to the development of the city, so it would be wrong to dismiss its impact when considering any future regulations or development of the old town. Otherwise, the Shrine, as with many 
other parts of Iraq, suffers from the neglect and mismanagement resulting from the instability of political regimes in the country over the ages. Hitherto, the central and local government regard how to accommodate visitors to the Shrine in a safe way as a priority, and forget the historical and cultural considerations. In sum, the Shrine is not just a physical building, but it carries tangible and intangible values, and it is associated with and bearer of local memory. Therefore, its effect is not only spatial, but extends temporally and spiritually, because the memory is the container of local awareness of the past. The significant thing that been discovered is the extent of the relationship between the Shrine and visitors, as well as how do we create from the relationship, principles and criteria to improve the city to be a contemporary, without compromising its local identity.

It is hard to know in quantifiable terms, the rate and the extent of loss of heritage in the Shrine, and it is perhaps even more difficult to find out what cultural property has been lost in general. This is because of the weakness of the conservation management processes on the ground, and the lack of documentation relating to most of the cultural heritage property. Simply put, the loss of cultural heritage property is irretrievable. Once an area or a building of historic, religious or architectural significance is demolished, no replica can ever hope truly to convey the same as the original. As was indicated earlier, central and local authorities of Najaf have adopted the rather unfortunate policy of 'freeing' significant monuments from their surroundings. Apart from the fact that some of these surroundings may be architecturally or historically significant, their demolition represents a loss of the authentic setting and urban context of the Shrine.

In sum, the Shrine was the dominant feature of the Holy City, but with such a massive extension it is becoming a small element in proportion to the whole complex. In fact, it seems that there is still no official inventory of Iraq's cultural heritage; therefore it is necessary to prepare such an inventory in the first place. Therefore, despite the failure to implement most of the architectural regulations and policies on the ground, and ineffectiveness of some of them in Najaf, the dominance and implications of the Shrine to the town is still clear. Overall, Iraqi cultural heritage in general is still under threat, as we have seen with this particular example in Najaf, and within the current discourse it seems that there is no conservation work being carried out on the ground.

\section{References}

[1] Pickard, R., (eds). Management of Historic Centres, Conservation of European Built Heritage Series, Spon Press: London \& New York, p. 4, 2001.

[2] Raouf, M. A., Najaf: Past and Present: Al-Mamoon house for Translation and Publishing: Baghdad, pp. 35-40, 2013.

[3] Mahboba, J., Najaf's Past and Present, Al-erffan: Saida, Lebanon, pp. 3036, 1934.

[4] Al-Hakim, H., Detailed of the History of Najaf: The History of Imam Ali Shrine, Al-Haydaria Library: Qom, pp. 21, 39, 2006. 
[5] Qazi, A.B., Mashhad Ali Amir Al Muminin, Najaf Al Ashraf: A Review on the Phases of Destruction and Restoration, Daily News Pakistan, 2011.

[6] Maher, S., Imam Ali Shrine in Najaf and Its Gifts and Antiques, Dar AlMaaref: Egypt, photo 4, 1969.

[7] Imam Ali Holy Shrine foundation, http://www.imamali.net/?part=1

[8] Tabbaa, Y., \& Mervin, S., Najaf the Gate of Wisdom: History, Heritage and Significance of the Holy City of the Shi'a, UNESCO: Paris, Amman, 2014.

[9] Dewan: Architects and Engineers, Urban renewal of the City centre of Holy Najaf, Republic of Iraq, Ministry of Municipalities and Public Work, General directorate of physical planning: Iraq, part 6, p. 43, 2012.

[10] Kamona, H.A., The Urban Structure of the Najaf Old Town: Problems and Solutions, Afaaq Najafiya: Najaf, p. 41, 2008.

[11] Kamona, H.A., The City and Its Architecture Impact in Summer, Directorate of Antiquities: Baghdad, 1971.

[12] Kamona, H.A., The Urban Structure of the Najaf Old Town: Problems and Solutions, Afaaq Najafiya: Najaf, p. 42, 2008.

[13] Imara, T., Personal communication (Interview), 8 October, 2014. Local citizen in Najaf.

[14] Kamona, H.A., Perception in the Reconstruction of the City of Najaf as a Capital of Islamic Culture 2012, Association forum posting in Najaf: Najaf, p. 62, 2010.

[15] Urban Planning Authority, Development Plan for the Najaf Old Town, Baghdad, 1986.

[16] Llewelyn Davies Yeang and ADEC, Holy City of Najaf: Master Planning, Republic of Iraq, Ministry of Municipalities and Public Work: Iraq, p. 33, Report 3, 2009.

[17] Mohammed, M. \& Hadi, E., The Best Way to Deal with the Centre of Najaf Old Town, Development and Planning, University of Baghdad: Baghdad, p. 11, 2011.

[18] Mahboba, J., Najaf's Past and Present, Al-erffan: Saida, Lebanon, p. 71, 1934.

[19] Imara, T., Personal communication (Interview), 8 October, 2014. Local citizen in Najaf.

[20] Kamona, H.A., The Impact of Heritage in the Development of Najaf's Architecture, Turath Al-Najaf, Al-Najaf cultural and religious heritage foundation: Najaf, p. 127, 2013.

[21] Attia, A.N., Personal communication (Interview), 29 November, 2014. PhD at University of Kufa, Iraq.

[22] Kamona, H.A., Architectural and Schematic Harmony between the Imam Ali Shrine and the old city, Publishing Society Forum: Najaf, 2009. 